\title{
Designs in and for learning-a theoretical framework
}

\author{
Staffan Selander
}

\section{Introduction}

I would like to start with two examples of different learning contexts. The first example stems from a period of time in my life when I couldn't read novels (they all seemed to be about authors going to Paris trying to write a novel), and when my own writing seemed dull and heavy. It so happened that I attended a weekend course on doing glassworks, and to my own surprise, I found that the glass "told me" what to do. I worked intensely with the glassworks during these two days, and later that summer I went to the glass-factory in Kosta in southern Sweden for a course in glass-blowing. I also took a course in Stockholm during the fall on how to make leaded glass.

I deepened my knowledge and skills during the following years. I bought a glass-kiln and learned about where to buy glass, and the characteristics of Bullseye glass, as well as how one could, or could not, mix older glass and re-melt it. I learned about the tools I needed to cut the glass into lines or circles, as well as how to drill and grind glass. I also learned how to prepare glass for burning and about burning curves, and when it was thereafter possible to open the kiln without damaging the glass. Finally, I studied glass designers from different periods of time, and the ways they had developed their glass craft/art. I went to Murano in Venice, and I visited glass galleries, museums and educational sites in Australia, Sweden, and Denmark. I came to a point when the form of a line on the glass could fill me with happiness. I enjoyed the aesthetic experience, and I planned to melt glass to build something new. I actually became quite good—as an amateur.

I even thought of changing my occupation, to be able to work at least half-time with glass, but realized soon enough that it was too late in my life. I would never become a professional glass designer or glass worker. It would also take me too many years to develop enough skills as well as to develop contacts with galleries and a public, not to mention the special niche of art and craft critique. However, the experience with glass led me back to my own writing, and to reading novels again, and I realized that the "word" was my "true" element.

This is first and foremost an example of a mixture between a non-formal learning context, developed by chance and deepened by personal interest and 


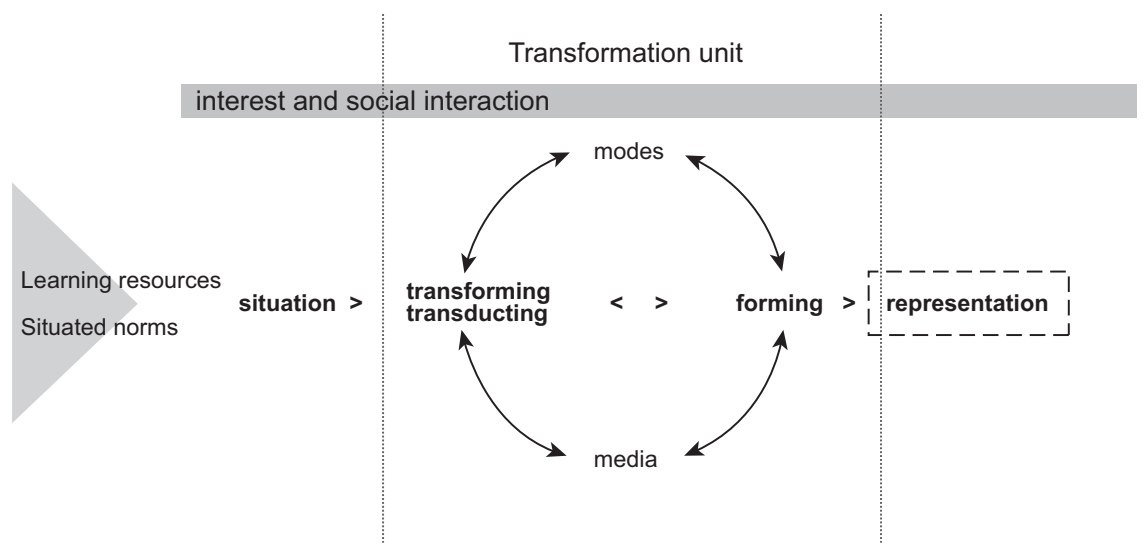

Figure I.I Non-formal Learning Design Sequence.

curiosity, and a semi-formal learning context - the different glass courses and glass museums. It also seems obvious that the glassworks I could do were not only a result of my personal interests and skills, but also of my social environment and my financial opportunities: the availability of courses with experienced glassworkers, the documentation of glass design through history, the possibility to buy tools, a kiln and special glass, as well as to visit glass galleries and museums. My own interest did not develop in an empty space.

This learning experience could theoretically be discussed in terms of a "Non-formal Learning Design Sequence" (Figure 1.1) and a "Semi-formal Learning Design Sequence (Figure 1.2). The first framing of my learning was when I went to a glass course, with its special material and semiotic resources, its norms and values, and its situated challenges. In different sequences I learned about glass, glass design and glass craft-both during the courses I took and by way of my own exploration of the characteristics of different glass materials. My glassworks could be seen as representations of my knowledge and skills, but they were not formally valued, and I did not have to pass any formal test to be able to continue with them. I learned from my own mistakes, even though we had teachers showing us the elementary ways of doing things, and from the more or less enthusiastic comments from my classmates and from my family and friends.

The main difference between the learning sequences in these two learning environments is that the non-formal learning sequence could start fortuitously, whilst the semi-formal learning sequence often has a clearer starting point (such as the setting of a museum exhibition) and is also framed by institutional aims and traditions, available objects, or the aspirations of the curator, for example. I think that it would be fair to say that most learning (as in these two different contextual framings) actually follows what we could call "rhizomatic webs" 


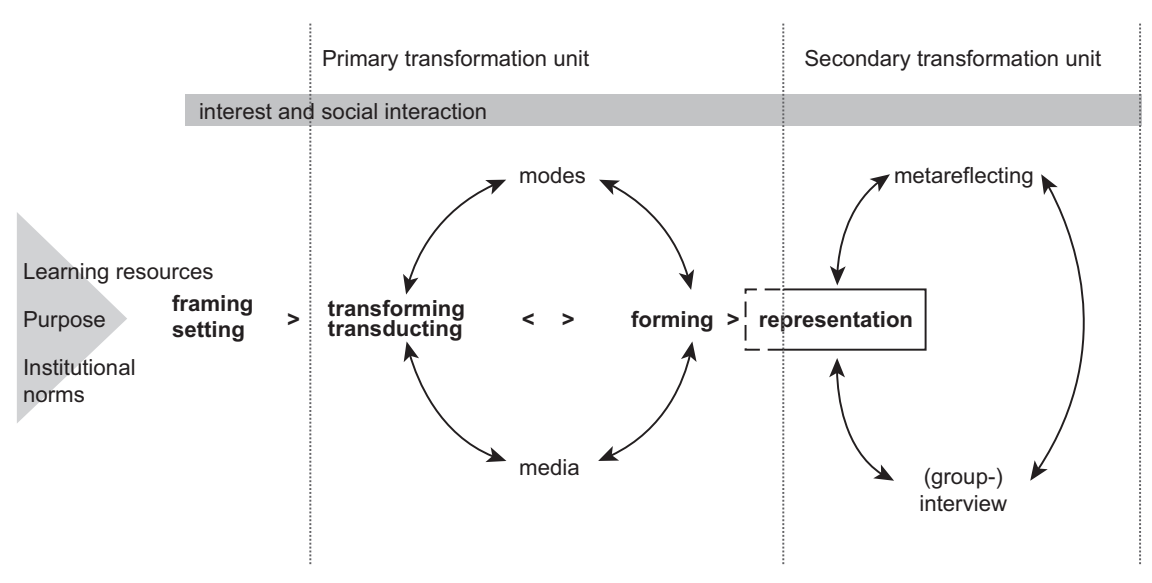

Figure I.2 Semi-formal Learning Design Sequence.'

(see Chapter 2 by Lindstrand \& Selander in this volume). A new idea, and new information, may lead to new questions; it may encourage us to continue on or change direction. Additionally, there is no curriculum to be fulfilled, and no necessary test to pass.

As a contrast, my next example stems from a formal learning context-the school. The subject is educational sloyd, here with a focus on woodcraft. ${ }^{2}$ When I went to school, sloyd was a part of the curriculum, stemming from the needs and skills in the pre-industrial society. I was 11-12 years of age, and the sloyd education focused on such things as the tools and the names of the different tools, and of course on the handicraft skills. ${ }^{3}$ Basic skills were taught first, and we had to learn (as it was seen at the time) formal, elementary things like sawing and planing before we were allowed to create something out of the material. While I was still planing-and it was important that my piece of wood should be absolutely plane from each side and angle-one of our classmates was allowed to make a chair.

After many weeks of planing, I was finally allowed to do carving, and during the rest of that semester I managed to make a little bowl. However, we were not taught anything about aesthetics or design related to three-dimensional forms and proportions, such as the relation between width and length, inner and outer proportions, or, for example, thickness in relation to cavity (Thorsnes, 2009). The idea was not that we should create or experience new possibilities out of our own interest, nor that we should find out new ways of exploring different materials. The important thing was to complete the curriculum, where one goal was that each individual should learn the same terminology and reach the same basic handicraft skills as everyone else. At the end, all our products were evaluated according to specific school-standards, including good order and good behaviour. 
To sum up, our second example could be discussed in terms of the "Formal Learning Design Sequence" (Figure 1.3). In this model, learning is understood as an activity that is formally framed and assessed. The learning was also in this case carried out in sequences, but with a heavy emphasis on common goals and testing standards, ${ }^{4}$ but this is not to say that evaluation as such is wrong. Evaluation cannot be avoided in a social context; it always takes place in one way or another (Boistrup, 2015). ${ }^{5}$ Here, the point is that that evaluation in a formal context is different from that in a non-formal or semi-formal (as in a museum) context, which may have consequences for individual engagement in a specific knowledge area.

In the formal Learning Design Sequence, we can notice a more clearly framed beginning, based on the purpose, and the curriculum and the standards of the school, as well as on the potential resources, norms, formal regulations, and so on. The "setting" starts with the teacher's interpretation of the frames, and the pupil's attention to-and understanding of-what is expected from them. The pupils can then, during the "First Transformation Cycle," work with available (and accepted) material and semiotic resources, test different solutions, and sketch out possible ways to talk about, or show, their understanding. Here we can also focus on other aspects, for example, how the teacher or the pupils position themselves in the learning space, and how their social interaction is carried out.

At the end, during "The Second Transformation Cycle," the pupils are expected to present their learning and new knowledge by way of a test, an essay, a film, or

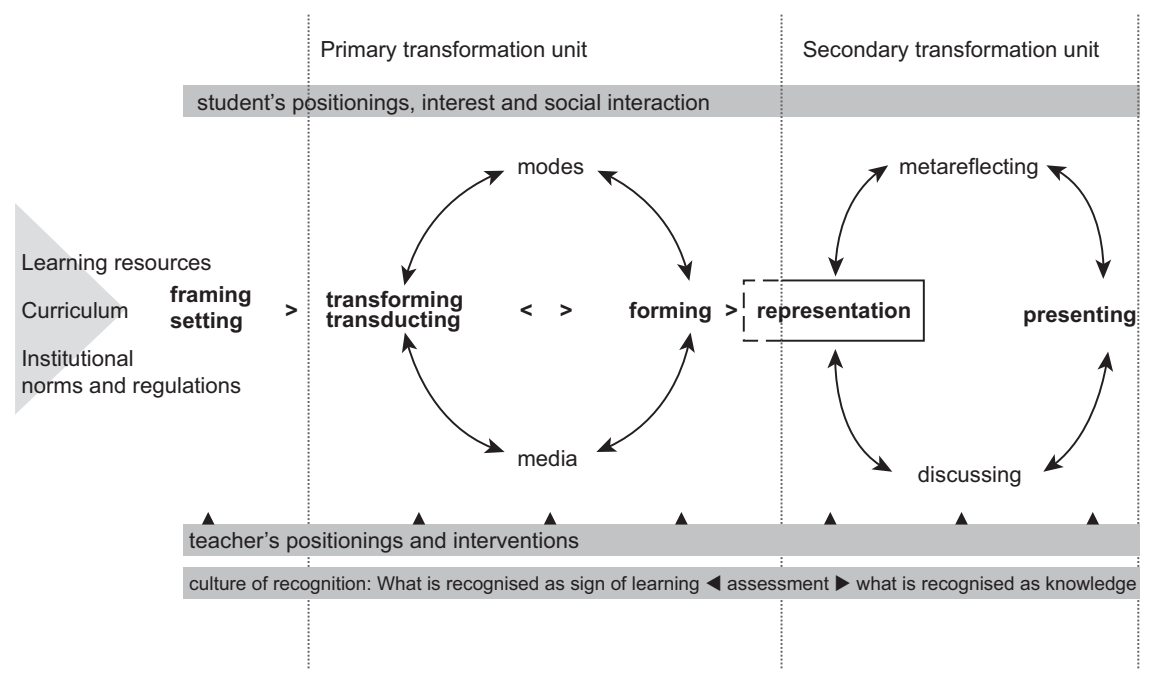

Figure I.3 Formal Learning Design Sequence. ${ }^{6}$ 
a PowerPoint; in other words, they produce a new knowledge representation. Their work is formally evaluated-sometimes also publicly discussed and reflected upon. $^{7}$ With these two examples in mind, we shall now move on to the basic concepts in a multimodal and design-oriented approach to learning. However, I would first like to make a short remark on "basic knowledge."

\section{A detour on "basic knowledge"}

The second example above also exemplifies the role of schooling in the industrial society, with the uttermost purpose to see that everyone, after education, could be employed in his or her "right" place in working life. Everyone had to acquire the same "core knowledge" or "basic knowledge," and they were evaluated and ranked according to standardized tests, no matter their individual interests, talents, or ideas about future work.

However, there seem to be at least two epistemological and ideological roots and implications of the idea of "necessary basic knowledge" for everyone. We can identify "basic knowledge" as that kind of knowledge that binds a society together-like social rules and habits, religious beliefs (and their variations), or, for example, knowledge about democracy and how one could handle conflicts (Burman, 2021). During earlier periods of time in history, such as the Renaissance and the Middle Ages, those things were discussed in religion, philosophy, and literature. The aim of schooling during those times was to learn about such things as rhetoric and grammar, music and mathematics, and to learn about oneself and what characterizes "good judgement" as well as "a good life" (Selander, 2017).

As a contrast to this ideal, the idea of "basic knowledge" changed at the end of the 20th century: from an overarching, common knowledge and individual grow th ${ }^{8}$ to the details of each separate school subject. ${ }^{9}$ So instead of seeing "basic knowledge" as that kind of knowledge that binds a society together (whatever that might be), the development seems to be accelerating towards a more and more fragmented and factual knowledge. Much of contemporary debate seems to be about "facts" and (the return of) "objective knowledge." At the same time, we seem to lack a serious debate on what kind of knowledge would be needed to meet future demands with complex and tricky problems, and what kind of knowledge would give insights into, for example, conflicting interests and power relations, as well as those things that characterize a good life (Bauman, 2012; Collins \& Halverson, 2009; Morin, 1999, 2008). ${ }^{10}$

So, if we are actually interested in "knowledge," we might as well develop a new kind of individually and digitally based tutoring system-within new social framings. For example, the Nobel prize-winning Swedish author Selma Lagerlöf had a governess, and learned, among other things, five languages. Today, we can likewise learn many things from distributed information and hybrid education, for example, by way of game-like elements in teaching, 
games, and simulation programs. Therefore, we would need new insights into what we mean by "knowledge," "learning," and "playing"11 in our contemporary time, as well as a more accurate understanding of how one could represent and assess multimodal knowledge representations (Arnseth et al., 2019; Brooks et al., 2021; Höglund, 2017; Lim, 2021; Kress \& Selander, 2012; Kress et al., 2021; Selander, 2008b).

\section{Design as a dynamic perspective}

Let us now return to the two examples above and the question of different designs for learning in different learning environments, and by way of different learning resources, learning goals, and cultures of recognition. If we ask ourselves how we could do research on learning in these two different cases, many possibilities are at hand. My own research journey started with sociology and the sociology of education, and it was not a big step to begin the study of the works of Vygotsky and the sociocultural understanding of collective memory, institutional framing, or social classes or strata, as well as the child's growing understanding of the world when she or he has developed language in her or his own milieu. But how to study the learning on different levels, both in terms of individual learning and learning within groups? Behavioural observations alone do not seem to be a good idea, because we then focus on behavioural change, which does not involve meaning-making. Likewise, to interview people on their meaning-making misses actual changes in their capacity to act in new ways, simply because people are blind to their own practice. Therefore, interview data alone do not give evidence of peoples' new skills and capacities in terms of their new abilities to act in different contexts, even though such additional information could be of importance. ${ }^{12}$

Later on, I came into contact with social semiotics and multimodal understandings of communication and meaning-making. Here I found detailed analysis of sometimes very short, communicative sequences with different resources, but much of these analyses took the "social" for granted. So, this tension between sociological (and social-psychological) views on learning, on the one hand, and the language-based, social semiotic view on meaningmaking, on the other, called for attention. And it was in this gap that I (and the research group in this volume ${ }^{13}$ ) started to elaborate on some basic questions:

1 How can we study situated meaning-making and new capacities to act in different, more or less formally framed, institutional contexts?

2 How can we construe a rigorous and productive methodology, which is based in a theoretical perspective, and which also takes the ethical research questions into consideration? 
3 How could a research perspective, which often analyzes what has happened, be combined with a perspective that is interested in innovative and problem-solving practices-what might happen - without losing our ambition to investigate and explain the processes? ${ }^{14}$

Out of these questions, we started to build a design-oriented perspective, with a focus on:

(a) how a multimodal analytical approach can be used to study multimodal communication and texts (in its wider sense), with an understanding of the institutional conditions for learning and knowledge representations (which in different ways are exemplified in Part 2 of this volume);

(b) the development of a theoretically, methodologically, and ethically oriented design-perspective (as in Part 1of this volume); and

(c) the different roles and responsibilities of researchers and professionals involved in collaborative, innovative processes.

Traditionally, the concept "design" refers to such activities as thinking and planning in order to manufacture a model or prototype that combines form and function - as in designs of cars, buildings, kitchen utensils, furniture, and clothing, or in the development of organizational structures and routines. During recent decades, the concept of design has changed character, towards meaning and function, collaborative cultures, digital design, and re-design. In line with this understanding of design, our perspective has a focus on meaning and function, especially on such aspects as learning and meaning-making, framing, re-design, knowledge representations, Learning Design Sequences, cultures of recognition, and signs of learning (see, e.g., Boistrup, 2010; Elm Fristorp \& Lindstrand, 2012; Insulander, 2010; Insulander et al., 2019; Kempe ${ }^{15}$ \& West, 2010; Kjällander, 2011; Rostvall \& Selander, 2010; Selander, 2008a, 2015; Selander et al., 2021; Selander \& Kress, 2017; Selander \& Svärdemo-Åberg, 2008; Åkerfeldt, 2014).

At large, this perspective draws upon two different, albeit related, educational and problem-solving traditions and experiences: the Nordic tradition of equal education, project-based learning, and further education as well as on "VolkBildung" (Arnseth et al., 2019; Sørensen, 2008; Sørensen et al., 2010) and the orientation of design towards meaning and function, collaborative work, user-oriented design and re-design (Brooks et al., 2021; Brandes et al., 2009; Brown, 2009; Dorst, 2015; Dunne, 2018; Knutsson et al., 2021; Marion \& Fixson, 2018; Verganti, 2009). We were especially inspired by design-oriented research perspectives, not least the relation between "doing research" and "doing innovative work" (Barab \& Squire, 2004; Clarke, 2018; Löwgren \& Stolterman, 2004; Redström, 2017); and a multimodal understanding of communication, semiotic resources and meaning-making (Bezemer \& Kress, 2016; Jewitt, 2012; Kress, 2010; van Leeuwen, 2005); as well as different design-oriented, sociocultural and anthropological research on education and learning (Collins 
et al., 2004; Laurillard, 2012; Lim, 2015, 2021; Säljö, 2005; Sheridan \& Rowsell, 2010; Sørensen et al., 2010; Wulf, 2013; Østern \& Strømme, 2014). ${ }^{16}$

In sum, our overarching concept of "design" refers to learning environments and resources, meaning-making and communication as institutionally and individually framed social practices. It is a theoretical and methodological tool for doing research and making detailed analyses of knowledge representations and learning processes, which look both at existing knowledge representations and at the representations and resources that are used by the learners in their multimodal production and re-design of new representations (Boistrup \& Selander, 2009; Insulander et al., 2019; Selander, 2017; Selander et al., 2021). It is also a theoretical and methodological tool for finding a way to take part in collaborative, systematic, innovative and developmental work in different sites, as, for example, with schools, museums, and communities (Glawe \& Selander, 2021; Halverson \& Kelly, 2017, also see Chapters 5 (Boistrup \& Hällback), 6 (Kjällander), and 9 (Insulander \& Svärdemo-Åberg, in this volume).

\section{Designs for learning-designs in learning}

"Designs for learning" also entails the perspective of "Designs in learning." Designs for learning refers to such things and processes that are produced and organized for learning, like school and museum buildings, school textbooks, schedules (or timetables), curricula, tests, teacher education, selection principles, school laws and regulations, objects, and artefacts. It also includes institutional traditions and social norms that have been developed over time, and so on.

Designs in learning, on the other hand, refers to learning processes and products, like interests, knowledge styles, ${ }^{17}$ habits concerning the use of different sources of information as well as different resources and techniques to produce sketches of the learning along the way (see "re-design" below). It also concerns aspects such as the preferable time of day to work with school tasks, whether the individual learner likes to discuss with others or not, and so on. And since the individual learner also can follow arbitrary associations and information tracks, their learning paths can be talked about as "rhizomatic webs" (see Chapter 2 by Lindstrand \& Selander in this volume). It is therefore important to know more about individual learners, and to develop the tools to handle massive and diverse individual data-by way of Artificial Intelligence, for example (Swiecki et al., 2017). It is also important that the individual learner is given a chance to learn more about his or her own learning (so called meta-learning) and that he or she learns how to use cultural tools for thinking (Barth, 2015; Säljö, 2005).

The model of Learning Design Sequences (Figures 1.1, 1.2, and 1.3) can be used to analyze the specific, contextual learning situation, to follow both the learner's and (as in Figure 1.3) the teacher's actions, or, for example, to study which resources are used, and how they are used, as well as to see what kinds of evaluative arrangements (formal tests, performances, etc.) are at play. 


\section{Framing}

Framing is a term with many different meanings, depending on its theoretical grounding. ${ }^{18}$ Here, we will use framing as a spatial and temporal bounding of significant bits of information. Framing can be studied both from the point of view of formal, institutional framing (as in a school with its curriculum and explicit goals and testing procedures, norms and regulations, teachers' planning, etc.) and from the point of view of individual framing (derived from social background, dispositions, ${ }^{19}$ hopes for the future, individual interests, and situated focus, ${ }^{20}$ - and therefore not primarily psychologically based). In our case, the concept of framing is also used to analyze and understand epistemic differences and power relations in the "between"-in the social meeting between the formal or semi-formal (institutionally framed) offerings, its demands and potential resources, and the individual's interests and acting.

However, we could also focus on the epistemological framing-on theoretically based definitions, hierarchies and networks of important or significant concepts (Bowker \& Star, 2000; Haack, 1996; Selander, 2018). In an educational, institutional context, epistemological framing highlights the formalized, subject-oriented concepts and procedures, and the educational task is to help the individual learner to re-frame his or her preliminary understanding and to learn to use the subject-oriented repertoire, in order to be able to talk about, or analyze, more domain-specific questions and problems. ${ }^{21}$

Epistemological framing could be discussed further in terms of emblematic and thematic framings, where the first concept points at the overarching organizing principle and the second at different specific sub-themes (Insulander et al., 2019). As an example, knowledge about the heart can be framed in many different ways. In an encyclopedia, the focus could be on such aspects as the heart, heart-diseases, cardiopulmonary rescue, or, for example, myocardial infarction, described by an expert for the non-expert.

In a school-textbook for the upper secondary school, the heart can be described under the heading "The blood and the circulation," where heartrelated problems are related to smoking, drinking, and snuffing-including a moral undertone. In a school textbook, a description usually ends with control-questions concerning some basic facts. In another textbook-under the heading "Heart and vascular diseases," aimed at vocational training for assistant nurses - the focus is rather on descriptions of heart problems, including such things as how to monitor patients.

The last example is from an edutainment game (an old CD-ROM disc!) with different concepts like the cardiac muscle, as well as pictorial illustrations to explore. Here, by way of gaming, we may also be transported inside a patient's body, asked to "save the patient" by zapping injured cells (Selander, 2003). These four examples show different epistemic framings: the first one focuses on the medical knowledge of organic structures and functions, presented for the interested non-expert; in the second, the school 
textbook frames the information from the curricular perspective (some basic facts and organic functions) with an additional moral tone of what is good and healthy behaviour, and what is not; the third example-aimed at preprofessional education of assistant nurses-frames the information from the point of view of medical treatment; and our last example combines descriptions and exploration with gaming elements. Each of these emblematic framings leads to different sub-themes, but they all represent "knowledge" about the heart.

The broader understanding of framing in problem-solving and innovative processes of products or in organizations (Dorst, 2015; Marion \& Fixson, 2018) can therefore also be used to analyze teaching and learning, in smaller or larger contexts (Halverson \& Kelly, 2017; Glawe \& Selander, 2021; Selander, 2017).

\section{Setting}

The concept of setting (in the Learning Designs Sequence model) can be used in the analysis of teaching and learning in a formal school-context to emphasize the duality of 1) the teacher's setting of the task for the pupils to work with, institutionally framed in terms of rules and regulations, norms and traditions, testing and grading, and so on; and 2) the individual pupil's setting of his or her own role as a learner, for example, as: (a) a person interested in this particular domain, and perhaps preparing him- or herself for a future job in the field; (b) a person who is uninterested in this particular knowledge domain, but who wants to have good grades for future studies, and therefore shows (some) interest in the knowledge domain; or (c) a person uninterested in the field or any future studies, and therefore disregards (this particular) schoolwork task.

However, setting can also be used to analyze the processes in a semi-formal museum-context, and the meeting between, on the one hand, the institutional resources and the aspirations of the curator and, on the other hand, the museum staff at large with the visitors (Insulander, 2010; also see Chapters 7 (Insulander, Lindstrand \& Selander), 8 (Insulander \& Öhman) and 9 (Insulander \& Svärdemo-Åberg) in this volume). It can also be used to analyze and reflect upon learning in a non-formal framing (as shown above in my introductory description of glassmaking).

\section{Re-design-the transforming and forming processes}

In a wider sense, re-design involves activities to change a given design in order to create something anew, as when you use an old teacup as a toothbrush stand, remake a chair to serve as a clothes hanger, or when you take information from the Internet and adapt it to the needs of a special group of pupils. Re-design 
can take the form of transformation to the same mode, as when text is transformed into a new text (Kress, 2010), or transduction, when, for example, a text is transformed into a pictorial illustration (Kress, 2010; also see Höglund, 2017; Lindstrand, 2006; Öhman-Gullberg, 2008). ${ }^{22}$

Here, I would also like to use the concept of re-design (as a metaphor) for learning activities. In a school context, a lesson may start by the setting of a learning task. The re-design includes (a) the reading and interpretation of existing knowledge representations, as well as (b) the different modes and media that individuals (or groups) are using to sketch their new understanding and finally create a new knowledge representation (see Figure 1.1, Figure 1.2, and Figure 1.3).

\section{Knowledge representations}

A knowledge representation can be understood as a frozen moment that produces a context-bound, situated affordance (see also Chapter 3 by Lindstrand in this volume). In a school context, pupils use knowledge representations in the form of different learning resources, which they must interpret before they design their own understanding; in our terminology this is a re-design of the (given) knowledge representation. This view also entails the idea of learning as a creative engagement which adds something to the world, as a contrast to the idea of learning as reproduction of "the given." 23 Knowledge representation underlines the role of materiality and semiotic modes for how something can be designed and interpreted, including such aspects as what is in focus and what is more in the periphery, what is taken for granted and what is seen as new, and so one (Kress, 2010; Kress \& van Leeuwen, 2021). Knowledge representation is, in this perspective, therefore different from the ideas of knowledge representations as "true representations," or, for example, "mirrors of reality." However, this does not mean that we have to leave behind the idea of solid scientific knowledge (Haack, 1996). ${ }^{24}$

Knowledge representations may also be discussed in terms of a wider concept of text, as in multimodal texts, and how different semiotic resources "go together" or "contradict" each other (Danielsson \& Selander, 2016). This includes a wider understanding of the concept of text as a multimodal, semiotic resource and a visual representation (Archer \& Newfield, 2014; Kress, 2003). In addition, I would also like to include interactive texts (if we see a game as a text) since this kind of text clearly involves action as a part of the understanding (Arnseth et al., 2019; see further Table 1.1).

In each of these ways to represent knowledge (as text, multimodal text, or interactive text), we can see different affordances according to choices of materiality, semiotic resources, and activities, and therefore also different possibilities to express knowledge and learning-something which relates to cultures of recognition and assessment standards in different domains as well (Kress \& Selander, 2012; Nouri et al., 2017). Of course, it is also possible to mix modes 
Table I.I Dominant understandings of "Texts" in relation to social and technological conditions. (modified from Selander, forthcoming)

\begin{tabular}{|c|c|c|}
\hline $\begin{array}{l}\text { Written and printed (ver- } \\
\text { bal) texts }\end{array}$ & $\begin{array}{l}\text { Multimodal texts/Visual } \\
\text { representations }\end{array}$ & Interactive texts \\
\hline $\begin{array}{l}\text { Text is defined as written } \\
\text { or printed letters } \\
\text { and words. Texts are } \\
\text { sequenced in a linear } \\
\text { way. }\end{array}$ & $\begin{array}{l}\text { A wider understanding of } \\
\text { text as visual representations } \\
\text { (pictorial illustrations, } \\
\text { graphs, etc.) and the role } \\
\text { of layout for meaning- } \\
\text { making. Multimodal texts } \\
\text { are sequenced according } \\
\text { to spatial principles }\end{array}$ & $\begin{array}{l}\text { Interactive texts change } \\
\text { according to the user's/ } \\
\text { actor's capabilities and } \\
\text { choices, and they are } \\
\text { sequenced on different } \\
\text { levels. }\end{array}$ \\
\hline $\begin{array}{l}\text { Reading is understood as } \\
\text { the capability to read } \\
\text { and decode letters } \\
\text { and words. You (most } \\
\text { often) learn to read } \\
\text { early on in life. }\end{array}$ & $\begin{array}{l}\text { A wider understanding of } \\
\text { reading as a capability to } \\
\text { understand multimodal } \\
\text { texts. You learn to read } \\
\text { different genres and types } \\
\text { of text throughout your } \\
\text { lifetime. }\end{array}$ & $\begin{array}{l}\text { Interactive texts relate to } \\
\text { the user's actions and give } \\
\text { constant feedback. To } \\
\text { understand a text is to act } \\
\text { in an accurate way. }\end{array}$ \\
\hline $\begin{array}{l}\text { Writing is understood as } \\
\text { the capability to write } \\
\text { letters, words and } \\
\text { sentences. }\end{array}$ & $\begin{array}{l}\text { A wider understanding of } \\
\text { writing also includes the } \\
\text { capability to compose } \\
\text { multimodal texts. }\end{array}$ & $\begin{array}{l}\text { Writing in relation to } \\
\text { interactive texts includes } \\
\text { acting with the program, and } \\
\text { also the (basic) capability } \\
\text { to program a game. } .^{25}\end{array}$ \\
\hline
\end{tabular}

and media in hybrid-teaching. In a Norwegian project aimed at developing pupils' understanding of music by way of composing music on iPads, the performative aspect of learning was strongly emphasized (Bandlien, 2019; Bandlien \& Selander, 2019).

\section{Signs of learning}

The question "How can we see that learning has taken place?" is of course central, yet very difficult to answer. We cannot see into the head of the learner; we have to judge from how learning manifests itself in the form of new capacities and new understandings, for example, in communication, in actions or through testing. This also means that it is possible that someone has learnt something which is not fully demonstrated or visible at a certain moment, or that one and the same person may show different aspects of what he or she has learnt depending on the test-situation (Säljö, 1998; see also Chapter 5 by Boistrup \& Hällback in this volume). It is, furthermore, the case that learning is an ongoing process-including new "aha moments" or insights as well as small adjustments in what has already been learnt - and therefore, learning is hard to capture at one single moment in time. We rather need a sequential thinking process, where we observe activities between (at least two) different "points in time." We should 
also remember that there is no such thing as the "same" testing situation on two different occasions - there are always some kind of intermediate variables that to some extent affect the testing situation. ${ }^{26}$

The term "learning" can mean many things. Learning is not only about increased individual and mental capacities. It also involves such aspects as bodily learning and social learning; it involves creativity and responsibility, as well as judgements of what is proper to do at a certain moment, and what is not (Nussbaum, 2011). Our learning depends on our brains, our bodies, and our social environment. Learning is not a "thing," but a "process." Still, even if "learning" is a floating term, it seems valuable and fruitful to talk about "learning," if we specify from which perspective we speak and what we include in the term. ${ }^{27}$ Learning involves ongoing change, and involves aspects such as acquiring a greater variety of stories, explanations, descriptions, and skills. From this point of view, it does not seem that fruitful to use metaphors like "surface learning" and "deep learning." A design-oriented understanding involves other perspectives and metaphors, oriented towards the richness of variations. ${ }^{28}$

We learn from school textbooks, but also from a rich variety of other resources. We learn in school-contexts, but also in all other contexts. And we learn different things depending on our personal (and socially embedded) aspirations and interests. We learn when we play, but also when we are focused on the learning of new things per se (e.g., multiplication or verbs in a new language). We learn what seems important in a certain environment, but also a lot of things besides (sometimes talked about as the "hidden curriculum") since we more or less consciously adapt to new situations.

To understand learning, we have to understand it as a process in a certain social environment-as a social practice (Kress et al., 2021). We can study learning by focussing on situated sequences, searching for "signs of learning," as well as being aware that these signs of learning are context-bound-dependent on what counts as learning in a certain assessment practice, which is bound by existing "cultures of recognition" (Kress \& Selander, 2012). ${ }^{29}$

\section{Learning design sequences}

Our model Learning Design Sequences (LDS) (Figures 1.1, 1.2 \& 1.3) is a theoretically-based, methodological tool to do empirical research on learning in different contexts. It is a tool that can help us to sort out important aspects, for example, communication and social interaction, activities, knowledge representations, or signs of learning. However, it is not a rigid model, to be followed in perfect detail. It is rather a heuristic tool, which in combination with other perspectives can give a structure for how to collect and analyze data (see Chapter 5 by Boistrup \& Hällback in this volume). Therefore, we can use a social semiotic and multimodal analysis of communication-but we do not have to do this. Such an analysis is rich and fruitful, but also time-consuming. The important thing is rather to keep in mind that we observe aspects of 
communication, activities, and the transformation of knowledge representations into new ones - which can be studied as signs of learning.

When we do this type of analysis, we first take a closer look at the conditions and frames, norms and regulations, traditions and potential resources, and so on. We then analyze the communication and the meaning-making activities and the outcome of these activities. Finally, we look more closely at the practices of evaluation and metareflections. However, elements from each of these three parts may also be present in other parts: we evaluate during the whole process, not only at the end of that process; students try out new ideas when learning, but teachers also do this when planning for new teaching activities (as in the first phase), and the communication between, for example, teachers and pupils, or between pupils, also takes place in the third phase. And, as we see in Chapter 4 by Åkerfeldt and Boistrup in this volume, the model can also be used to reflect upon ethical dilemmas that might occur during different stages in the research process.

Besides this, the LDS model can also be used as an instrument for planning learning sequences as a teacher. If so, the order is likely to be changed. The starting point is rather the third phase: what is the result we want to achieve? Then comes the reflection on the first phase: curricula, norms, traditional habits, new resources for learning, and so on. Finally comes the second phase in the model: the activities and signs of learning we want to plan for, and observe, during the learning process.

\section{Concluding remarks on designs for learning}

Designs for Learning is a way to discuss and study learning in different (nonformal, semi-formal, and formal) contexts. It is a way to conceptualize learning in different hybrid environments, where information is distributed and playful elements may be a part of the learning process (Lindstrand et al., 2016). It gives attention to such framing aspects such as norms, regulations and traditions, as well as to which material and semiotic learning resources are at hand. It focuses on learning sequences and the ways the learner expresses and communicates his or her understanding, and it gives attention to activity spaces, mimetic learning, and agency, as well as to cultures of recognition. In other words, this is a way to conceptualize learning as a social practice (Kress et al., 2021).

We use the concept of "design" as a metaphor in a wider sense, but also to outline a theoretical grounding, and a methodological strategy - the Learning Design Sequence model - for doing empirical research. Furthermore, design also outlines a way to organize partnerships in innovative learning processes (Glawe \& Selander, 2021; Insulander et al., 2017; Selander, 2017; Selander \& Kress, 2017). ${ }^{30}$

\section{Notes}

1 Figures 1 and 2 are slightly changed compared to the first models from 2008, and developed from discussions in Kvinge (2019), Nouri (2014), Åkerfeldt (2014), and others. 
2 "Sloyd" in Swedish "slöj," focuses on different materials and techniques: woodwork like sawing and planing; metalwork like soldering and welding; or work with fabrics like sewing and knitting. Today we can find a slightly more creative approach, with, for example, designs of patterns and combinations of mixed materials and techniques (including digital devices).

3 Perhaps someone thinks that it is unfair to compare the learning of a grown-up man with that of a young boy, since the former can think of the consequence of his choices in another way than a boy could. However, if we think of learning in a broader sense as a social practice (see Kress et al., 2021) and what drives learning, there might not be that sharp a difference. It is rather a matter of how we institutionally and epistemically frame communication and learning (also see Selander, 2018).

4 The rhetoric about school standards is often related to individual achievements and "just" evaluations, but school-testing is more often steered by the need to sort individuals from each other, and to rank them.

5 Just think of all the evaluative statements or expressions we use in everyday life, like wonderful, beautiful, delicate, smart, or elegant, and their possible contrasts, like horrible, ugly, stale, stupid, or clumsy.

6 Figure 1.3 is slightly changed compared to the first models from 2008, and developed from discussions in Kvinge (2019), Nouri (2014), Åkerfeldt (2014), and others.

7 Reflections and discussions on a smaller scale also take place in relation to each "choice" during the learning process in "The First Transformation Cycle."

8 Which have been discussed in terms of "Bildung" and "Liberal Arts."

9 It seems that the only outcome of this is that youngsters spend more and more time in schools to do (more or less) the same thing, and that the official purpose seems to be to uphold a good ranking in international testing. A vital question we could ask is: for how long will it be possible (economically speaking) to uphold, and further expand, this system (given that a fifth or a fourth of youngsters will fail)? And another is: what would it take to develop individual interests within a common, social framing?

10 When the Swedish government recently encouraged lowering the age of starting schooling from seven years of age to six, one of the main arguments was the need to reach "knowledge goals." However, such goals are historically situated, and seem in this case to be mainly devoted to international "contests" on testing. We can notice that the main argument was not, as in the discussions within other OECD-countries, to develop knowledge and skills and prepare for a future, complex democratic society with creative and collaborative individuals. We could also think of what democratic value the argument above would have had during the time of fascistic regimes of the 1930s and '40s, when textbooks in, for example, Germany and Italy praised the dictator and his party (see, e.g., Teistler, 2006). And what would this have meant in terms of "knowledge goals"?

11 To play indicates in many contexts something different from work, something you do for fun, or something you do in your spare-time-in other words, something that is not really serious. As a contrast, we can find more interesting and elaborated ideas on play by, for example, Caillois (1967), Gallagher (2015), Karoff (2013), and Pellegrini (1995).

12 Outcomes of social actions are not one-directed consequences of intentions, even if intentions and endeavors towards certain goals give some directions for our acting. It is also the case that our intentions and endeavors are partly consequences of social conditions, embedded in habits, expectations, and world view, and so on. It can also be of interest to notice that the role of interviews in sociological research rapidly increased at the end of the 1960s, when portable tape recorders made mobile recording possible. Then we also had many so called "report" books. Today, we can see something like this, since digital and portable cameras make it possible to film many different social interactions and activities, and thus enable more detailed multimodal analysis of social communication and ways of working with different resources.

13 Also see Selander et al. (2021). 
14 This question also involves a perspective on what scientific work is about. During the peak of logical empiricism in Vienna during the 1920s, the dominant idea was that natural science should be the guide for all kind of scientific work. Later on, in 1959, the physical chemist Charles Percy Snow (2012) gave a famous talk about the two cultures and the differences between the humanities and the natural sciences (something which had already been discussed at the end of the 19th century by, for example, Wilhelm Dilthey, 1996). As a next step, Jerome Kagan (2009) introduced the idea of the three cultures: the natural sciences, humanities, and social sciences, and the differences between them in terms of questions, types of evidence, vocabulary, the influences of historical and social parameters, the role of ethical reflections, and the criteria for elegance in the presentation of findings. Perhaps it is now time to talk about the four cultures, since design-oriented thinking includes involvement in innovative work as well as reflections on designs as a basis for theoretical work (Selander, 2017; also see Barab \& Squire, 2004; Redström, 2017).

15 Previously Anna-Lena Rostvall.

16 Even though we as a research-group share many of the central thoughts on "designs for learning," each individual researcher has his or her own take on this perspective, depending on research interest and research questions. As the reader will find out, some relate more strongly to multimodal semiotics, others move towards ethnographic, communicative studies, and so on. As I see it, these variations uphold a dynamic discussion, and make it possible to further develop the perspective of "designs for learning."

17 It may be all too vague to talk about "learning styles" since there seems to be no real evidence for the value of this. However, "knowledge styles" refers to such aspects as: ways of reasoning, for example, going from the whole to the parts or the parts to the whole, or which kinds of knowledge representations are preferable for different individuals, like longer text, tables, illustrative examples, and so on.

18 We can find organizational perspectives (like the frame-factor theory (Lundgren, 1972); Goffman's analysis of front-stage and back-stage as different ways to frame social communication (Goffman, 1990); or, for example, different psychological or sociological views on "schemes of interpretation").

19 What Bourdieu (2010) also discusses in terms of habitus.

20 Kress (2010) has a similar discussion on "affordance" as a potential meaning, and "prompt" as an actualized meaning in relation to individual interests.

21 Similar concepts are, for example, contextualization, and the social principles of de-contextualizing and re-contextualizing, as Basil Bernstein (1973) formulated this: "Any formal educational experience entails de-contextualizing and re-contextualizing. In ways we do not properly understand, informal everyday experience, everyday communication within the family and peer group, creates procedures and performances fundamental to formal education. However, formal education selects, refocusses and abstracts from such experience, and in so doing de-contextualizing" (Bernstein, 1973, p. 30). Bernstein also talked about the differences between the working-class kids' "restricted and contextbound codes," and the middle-class kids" "elaborated and context-independent codes," where the latter was closer to the codes that dominated in the school-context.

22 This definition may be tricky. Kress (2010) uses the definition of transformation as a change within "the same" mode, and transduction as a change to "a different" mode, and that "mode" should be understood in relation to Halliday's three communicative aspects (p. 87). Kress also relates the use of the term "mode" to: (a) What is the social and cultural domain that it covers? and (b) What can a mode do in the cultural domain that it 'covers"? (p. 84). The term "mode" becomes even more complex if we discuss "mode" in relation to "medium:" for example, is "writing" the same mode when it is produced by hand, by typing on a typewriter or using the computer keyboard? Kress also discusses whether image, speech, gesture, or, for example, writing are "modes" or not (p. 84) noting that what we "do" in these three different cases seems to be different kinds of 
activities in terms of planning, and changing a text, linking it to other texts, and so on. There seems to be no absolute definition of the term "mode;" still it can be useful as a stipulated definition and context-bound clarification, to analyze aspects of knowledge representations and communication within a specific cultural domain.

23 In fact, humans never reproduce "the same," not in rituals, nor in learning. Even if we reshape anew, like in rituals and performances or in mimetic learning, we always change something, even if it may "only" be a tiny little bit — as a contrast to computer logarithms, which can produce "the same" (Deleuze, 2001; Wulf et al., 2010). This standpoint is also close to Bakhtin's (1982) idea that you can never totally "close" an utterance. There is always something new to add.

24 Haack also has an interesting discussion of the differences between "foundationalism" vs. "coherentism," and discusses variations of "foundationalism" in terms of: 1) theory of justification builds on "basic" or "derived" beliefs; 2) justification as an "analytic enterprise"; and 3) criteria of justification stand in need of "objective grounding" Haack, 1996, p. 186). She argues that this does not mean we cannot make rigorous and serious scientific analysis.

25 Programming is a part of computational thinking, which includes the capacity to analyze a phenomenon and create a solution by way of coding a program. Coding can be done by way of words and symbols, or by way of pre-produced visual segments.

26 This is also a reason for having portfolios on which pupils/students work over time.

27 A "word" is defined by its lexical and social use; a "term" is related to a more restricted, professional use; and a "concept" is defined within a theoretical frame. Therefore, the "same" word may mean different things in different social and epistemic contexts.

28 A similar change of perspective is discussed by Chomsky. In his earlier works, Chomsky developed a critique against Skinner's behaviouristic perspective on language-learning, and emphasized that language is something unique to the human species, based on the construction of the brain, making a distinction between the "surface" structure (the speech) and the "deep" structure (the grammar). Inspired by computer research, Chomsky now rather talks about the capacity of the brain to take any syntactic elements and construct new, hierarchical structures (Berwick \& Chomsky, 2016). Here, the emphasis is on the capacity to create structures, rather than any elementary language structure.

29 However, it is not always clear which kind of rationality actually lies behind a specific assessment practice. For example, is musical skill and knowledge the only thing that counts in a musical testing situation (Sandberg-Jurström et al., 2021)?

30 Our approach can also be seen as one answer to the dilemmas of educational research and the role of designs for learning discussed by Halverson \& Halverson (2020).

31 The title reflects a playing with words: "Kobran" was a telephone introduced by the company L M Ericsson in 1956, named "the cobra" due to its shape. "Nallen" was another word for the teddy-bear, but also a nickname for the cellphone when it became largely used in the 1990s, and "Majjen" was a nickname for the teacher. The title of the book implies the question of what changes and what does not (Selander, 2003).

\section{References}

Åkerfeldt, A. (2014). Didaktisk design med digitala resurser. En studie av kunskapsrepresentationer $i$ en digitalisera skola [Didactic design with digital resources: A study of knowledge representations in a digitized school]. Doctoral dissertation. Stockholm University.

Archer, A., \& Newfield, D. (Eds.). (2014). Multimodal approaches to research and pedagogy: Recognition, resources, and access. Routledge.

Arnseth, H. C., Hanghøj, T., Henriksen, T. D., Misfeldt, M., Ramberg, R., \& Selander, S. (Eds.). (2019). Games and education: Designs in and for learning. Brill/Sense. 
Bakhtin, M. (1982). The dialogical imagination. University of Texas Press.

Bandlien, B. T. (2019). Ungdomsskoleelevers komponering med garageband på iPad. En musikdidaktisk studie av performative stopp-punkter i et kritisk designteoretisk perspektiv [Secondary school pupils composing with GarageBand on iPad: A music educational study of performative stop-moments in a critical design-theoretic perspective]. Doctoral dissertation. NTNUNorges teknisk-naturvitenskaplige universitet.

Bandlien, B. T., \& Selander, S. (2019). Designing as composing music with iPads: A performative perspective. In A.-L. Østern \& K. N. Knudsen (Eds.), Performative approaches in arts education: Artful teaching, learning and research (pp. 81-96). Routledge.

Barab, S., \& Squire, K. (2004). Design-based research: Putting a stake in the ground. The Journal of Learning Sciences, 13(1), 1-14.

Barth, B.-M. (2015). Le savoir en construction. Former à une pédagogie de la compréhension. Retz. Bauman, Z. (2012). Liquid modernity. Polity Press.

Bernstein, B. (1973). Class, codes and control: Vol. 3: Towards a theory of educational transmission. Routledge \& Kegan Paul.

Berwick, R. C., \& Chomsky, N. (2016). Why only us? Language and evolution. The MIT Press.

Bezemer, J., \& Kress, G. (2016). Multimodality, learning and communication: A social semiotic frame. Routledge.

Boistrup, L. B. (2010). Assessment discourses in Mathematics classrooms. A multimodal social semiotic $s t u d y$. Doctoral dissertation. Stockholm University.

Boistrup, L. B. (2015). Governing through implicit and explicit assessment acts: Multimodality in mathematics classrooms. In M. Hamilton, R. Heydon, K. Hibbert, \& R. Stooke (Eds.), Negotiating spaces for literacy learning: Multimodality and governmentality (pp. 131-148). Bloomsbury Books.

Boistrup, L. B., \& Selander, S. (2009). Coordinating multimodal social semiotics and an institutional perspective in studying assessment actions in mathematics classrooms. In V. Durand-Guerrier, S. Soury-Lavergne, \& F. Arzarello (Eds.), Proceedings of CERME 6, Sixth Conference of European Research in Mathematics Education (pp. 1565-1574). Institut national de recherche pédagogique.

Bourdieu, P. (2010). Distinction. Routledge.

Bowker, G. C., \& Star, S. L. (2000). Sorting things out: Classifications and its consequences. The MIT Press.

Brandes, U., Stich, S., \& Wender, M. (2009). Design by use: The everyday metamorphosis of things. Birkhäuser Verlag AG.

Brooks, E., Dau, S., \& Selander, S. (Eds.). (2021). Digital learning and collaborative Practices: Lessons from inclusive and empowering participation in emerging technologies. Routledge.

Brown, T. (2009). Change by design: How design thinking transforms organizations and inspires innovation. Harper Business.

Burman, A. (2021). Dissensus. Drömmar och mardrömmar i demokratins idéhistoria [Dissensus: Dreams and nightmares in the history of ideas of democracy]. Natur \& Kultur.

Caillois, R. (1967). Les jeux et les hommes. Gallimard.

Clarke, A. J. (Ed.). (2018). Design anthropology: Object cultures in transition. Bloomsbury Academic.

Collins, A., \& Halverson, R. (2009). Rethinking education in the age of technology: The digital revolution and schooling in America. Teachers College Press.

Collins, A., Joseph, D., \& Bielaczyc, K. (2004). Design research: Theoretical and methodological issues. The Journal of Learning Sciences, 13(1), 15-42. 
Danielsson, K., \& Selander, S. (2016). Reading multimodal texts for learning: A model for cultivating multimodal literacy. Designs for Learning, 8(1), 25-36.

Deleuze, G. (2001). Difference and repetition. Continuum.

Dilthey, W. (1996). Hermeneutics and the study of history: Selected works: Volume IV [From Gesammelte Schriften 1860-1903]. Princeton University Press.

Dorst, K. (2015). Frame innovation: Create new thinking by design. The MIT Press.

Dunne, D. (2018). Design thinking at work: How innovative organizations are embracing design. University of Toronto Press.

Elm Fristorp, A., \& Lindstrand, F. (2012). Design för lärande i förskolan [Designs for learning in pre-schools]. Norstedts.

Gallagher, C. (Ed.). (2015). Minecraft in the classroom: Ideas, inspiration, and student projects for teachers. Peachpit Press.

Glawe, M., \& Selander, S. (2021). Innovativ design för lärande [Innovative designs for learning]. Liber.

Goffman, E. (1990). The presentation of self in everyday life. Penguin Books.

Haack, S. (1996). Evidence and inquiry: Towards reconstruction in epistemology. Blackwell.

Halverson, R., \& Halverson, E. (2020). Education as design for learning: A model for integrating education inquiry across research traditions. In T. Popkewitz \& G. Fan (Eds.), International handbook on education policy studies (pp. 201-222). Springer Singapore.

Halverson, R., \& Kelly, C. (2017). Mapping leadership: The tasks that matter for improvng teaching and learning in schools. Jossey-Bass.

Höglund, H. (2017). Video poetry: Negotiation literary interpretations: Students' multimodal designing in response to literature. Doctoral dissertation. Åbo Academy University Press.

Insulander, E. (2010). Tinget, rummet, besökaren. Om meningsskapande på museum [The object, the room, the visitor: Meaning-making in museums]. Doctoral dissertation. Stockholm University.

Insulander, E., Kjällander, S., Lindstrand, F., \& Åkerfeldt, A. (Eds.). (2017). Didaktik $i$ omvandlingens tid. Text, representation, design [Education in a time of change: Text, representation, design]. Liber.

Insulander, E., Lindstrand, F., \& Selander, S. (2017). The design of knowledge representations in different multimodal texts about the Middle Ages. Journal of Educational Media, Memory and Society, 9(2), 1-14.

Insulander, E., Lindstrand, F., \& Selander, S. (2019). Design för lärande-Historia. Medeltiden som exempel [Designs for learning: History: The Middle Ages as an example]. Liber.

Jewitt, C. (2012). Technology, literacy and learning: A multimodal approach. Routledge Falmer.

Kagan, J. (2009). The three cultures: Natural sciences, social sciences and the humanities in the 21st century. Cambridge University Press.

Karoff, H. S. (2013). Om leg. Legens medier, praktikker og stemninger [About play: The media and practices of play, and play moods]. Akademisk Forlag.

Kempe, A.-L., \& West, T. (2010). Design för lärande i musik [Designs for learning in music]. Norstedts.

Kjällander, S. (2011). Designs for learning in an extended digital environment: Case studies of social interaction in the Social Science classroom. Doctoral dissertation. Stockholm University.

Knutsson, O., Ramberg, R., \& Selander, S. (2021). Designs for learning and knowledge representations in collaborative settings. In E. Brooks, S. Dau, \& S. Selander (Eds.), Digital learning and collaborative practices: Lessons from inclusive and empowering participation in emerging technologies (pp. 12-21). Routledge. 
Kress, G. (2003). Literacy in the new media age. Routledge.

Kress, G. (2010). Multimodality: A social semiotic approach to contemporary communication. Routledge.

Kress, G., \& Selander, S. (2012). Multimodal design, learning and cultures of recognition.

The Internet and Higher Education, 12. https://doi.org/10.1016/j.iheduc.2011.12.003

Kress, G., Selander, S., Säljö, R., \& Wulf, C. (Eds.). (2021). Learning as social practice: Beyond education as an individual enterprise. Routledge.

Kress, G., \& van Leeuwen, T. (2021). Reading images: The grammar of visual design. Routledge.

Kvinge, Ø. R. (2019). Presentation in teacher education. A study of student teachers' transformation and representation of subject content using semiotic technology. Doctoral dissertation. University of Bergen.

Laurillard, D. (2012). Teaching as a design science: Building pedagogical patterns for learning and technology. Routledge.

Lim, K. Y. T. (2015). Disciplinary intuition and the design of learning environments. Springer.

Lim, V. F. (2021). Designing learning with embodied teaching: Perspectives from multimodality. Routledge.

Lindstrand, F. (2006). Att göra skillnad. Representation, identitet och lärande i ungdomars arbete och berättande med film [Making difference: Representation, identity and learning in youth film production]. Doctoral dissertation. HLS Förlag.

Lindstrand, F., Insulander, E., \& Selander, S. (2016). Mike the Knight in the neo-liberal era: A multimodal approach to children's multi-media entertainment. Journal of Language and Politics, 15(3), 337-351.

Löwgren, J., \& Stolterman, E. (2004). Thoughtful interaction design: A design perspective on information technology. The MIT Press.

Lundgren, U. P. (1972). Frame factors and the teaching process: A contribution to curriculum theory and theory on teaching. Almqvist \& Wicksell.

Morin, E. (1999). Le sept savoirs nécessaires à l'éducation du futur. Seuil.

Morin, E. (2008). On complexity. Hampton Press.

Marion, T. J., \& Fixson, S. K. (2018). The innovation navigator: Transforming your organization in the era of digital design and collaborative culture. University of Toronto Press.

Nouri, J. (2014). Orchestrating scaffolded outdoor mobile learning activities. Doctoral dissertation. Stockholm University.

Nouri, J., Åkerfeldt, A., Fors, U., \& Selander, S. (2017). Assessing collaborative problemsolving skills in technology-enhanced learning environments: The PISA framework and modes of communication. Journal of Emerging Technologies in Learning, 12(4), 163-174.

Nussbaum, M. (2011). Creating capabilities: The human development approach. The Belknap Press of Harvard University Press.

Öhman-Gullberg, L. (2008). Laddade bilder. Representation och meningsskapande i unga tjejers filmberättande [Charged pictures: Representation and meaning-making in young girls' film creations]. Doctoral dissertation. Stockholm University.

Østern, T. P., \& Strømme, A. (Eds.). (2014). Sanselig didaktisk design. SPACE ME [Aesthetic educational design: SPACE ME]. Fagbokforlaget.

Pellegrini, A. D. (Ed.). (1995). The future of play theory. State University of New York Press. Redström, J. (2017). Making design theory. The MIT Press.

Rostvall, A.-L., \& Selander, S. (Eds.). (2010). Design för lärande [Designs for learning]. Norstedts. Säljö, R. (1998). Thinking with and through artifacts: The role of psychological tools and physical artifacts in human learning and cognition. In D. Faulkner, K. Littleton, \& M. Woodhead (Eds.), Learning relationships in the classroom (pp. 54-66). Routledge. 
Säljö, R. (2005). Lärande och kulturella redskap: om lärprocesser och det kollektiva minnet [Learning and cultural artefacts: On learning processes and collective memory]. Norstedts Akademiska Förlag.

Sandberg-Jurström, R., Lindgren, L., \& Zandén, O. (2021). Musical skills, or attitude and dress style? Meaning-making when assessing admission tests for Swedish specialist music teacher education. Research Studies in Music Education. Advance online publication. https://doi.org/10.1177/1321103X20981774

Selander, S. (2003). Skolans blick—världen som text [The gaze of the school: The world as text]. In S. Selander (Ed.), Kobran, nallen och majjen. Tradition och förnyelse $i$ svensk skola och skolforskning [The cobra, the cell-phone and the teacher: ${ }^{31}$ Tradition and renewal in Swedish schools an in educational research] (pp. 91-109). Forskning i fokus, nr. 12. Myndigheten för skolutveckling.

Selander, S. (2008a). Designs for learning: A theoretical perspective. Designs for Learning, 1(1), 10-24.

Selander, S. (2008b). Designs for learning and ludic engagement. Digital Creativity, 19(3), 199-208.

Selander, S. (2015). Conceptualization of multimodal and distributed designs for learning. In B. Gros, Kinshuk, \& M. Maina (Eds.), The futures of ubiquitous learning: Learning designs for emerging pedagogies (pp. 97-113). Springer.

Selander, S. (2017). Didaktiken efter Vygotskij—design för lärande [Post-Vygotskian education: Designs for learning]. Liber.

Selander, S. (2018). Can a sign reveal its meaning? On the question of interpretation and epistemic context. In S. Zhao, E. Djonov, A. Björkvall, \& M. Boeriis (Eds.), Advancing multimodal and critical discourse studies (pp. 67-79). Routledge.

Selander, S. (forthcoming). A design-theoretic and multimodal approach to language teaching and learning. In S. Ørevik \& S. Diamantopoulou (Eds.), Multimodality and English: Affordances of multimodal texts in the teaching and learning of English as an additional language (pp. $\mathrm{xxx}-\mathrm{xxx}$ ). Routledge.

Selander, S., Insulander, E., Kempe, A.-L., Lindstrand, F., \& West, T. (2021). Designs for learning: Designs in learning. In G. Kress, S. Selander, R. Säljö, \& C. Wulf (Eds.), Learning as social practice: Beyond education as an individual enterprise (pp. 30-40). Routledge.

Selander, S., \& Kress, G. (2017). Design för lärande—ett multimodalt perspektiv [Designs for learning: A multimodal perspective]. Studentlitteratur. (original work published by Norstedts in 2010).

Selander, S., \& Svärdemo-Åberg, E. (Eds.). (2008). Didaktisk design i digital miljö—nya möjligheter för lärande [Didactic design in digital environments: New opportunities for learning]. Liber.

Sheridan, M. P., \& Rowsell, J. (2010). Design literacies: Learning and innovation in the digital age. Routledge.

Snow, C. P. (2012). The two cultures. Cambridge University Press.

Sørensen, B. H. (2008). Didaktisk design för "seriösa spel" [Didactic design for "serious games”]. In S. Selander \& E. Svärdemo-Åberg (Eds.), Didaktisk design i digital miljö—nya möjligheter för lärande [Didactic design in digital environments: New opportunities for learning] (pp. 172-186). Liber.

Sørensen, B. H., Audon, L., \& Tweddel Levinsen, K. (2010). Skole 2.0 [Education 2.0]. Klim.

Swiecki, Z., Misfeldt, M., Stoddard, J., \& Shaffer, D. W. (2017). Dependency-centered design as an approach to pedagogical authoring. In Y. Baek (Ed.), Game-based learning: Theory strategies and performance outcomes (pp. 169-188). NOVA. 
Teistler, G. (Ed.). (2006). Lesen lernen in Diktaturen der 1930er und 1940er Jahre. Fibeln in Deutschland, Italien und Spanien [Learning how to read during the German, Italian, and Spanish dictatorships in the 1930s and 1940s]. Studien zur Internationalen Schulbuchsforschung, Schriftenreihe des Georg-Eckert-Instituts, Band 116. Verlag Hahnsche Buchhandlung.

Thorsnes, T. (2009). Studier i tredimensionell form [Studies in three-dimensional form]. In F. Lindstrand \& S. Selander (Eds.), Estetiska lärprocesser-upplevelser, praktiker, kunskapsformer [Aesthetic learning processes: Experiences, practices, and forms of knowledge] (pp. 31-49). Studentlitteratur.

van Leeuwen, T. (2005). Introducing social semiotics. Routledge.

Verganti, R. (2009). Design-driven innovation: Changing the rules of competition by radically innovating what things mean. Harvard Business Press.

Wulf, C. (2013). Anthropology: A continental perspective. University of Chicago Press.

Wulf, C., Althans, B., Audehm, K., Bausch, C., Göhlich, M., Sting, S., Tervooren, A., Wagner-Willi, M., \& Zirfas, J. (Eds.). (2010). Ritual and identity: The staging and performing of rituals in the lives of young people. Tufnell Press. 